\title{
Characteristics of Information Systems and Business Informatics Study Programs
}

\author{
Markus HELFERT \\ School of Computing, Dublin City University \\ Glasnevin, Dublin 9, Ireland \\ e-mail: markus.helfert@computing.dcu.ie
}

Received: October 2010

\begin{abstract}
Over the last decade there is an intensive discussion within the Information Systems (IS) and Informatics community about the characteristics and identity of the discipline. Simultaneously with the discussion, there is an ongoing debate on essential skills and capabilities of IS and Business Informatics graduates as well as the profile of IS programs. With this paper we recognize the need for different IS perspectives resulting in diverse study profiles. We developed a framework for structuring information systems study programs and characterized some of the differences in study programs. The results from this study are based on a survey and workshops with domain exerts, both from academia and practice. The descriptive results from the survey are presented, and show the diversity of study programs, both on master and bachelor level. As an example for an IS profile we summarize a reference structure for Business Informatics study programs, which aims to provide guidance for curriculum development and to stimulate further debate on IS curriculum development.
\end{abstract}

Keywords: information systems, business informatics, curriculum, study programs, study profile.

\section{Introduction}

Within the Information Systems (IS) discipline there is an extensive and ongoing discussion about the core concepts and characteristics of the discipline. Due to the high controversy of the discussion and the unclear direction of the IS discipline, the discussion is often summarized as the "identity crises of IS". In response to Benbasat and Zmud's (2003) contribution about the identity crises of IS much debate has been focused on what constitutes IS as a discipline (Hirschheim and Klein, 2003). The perspectives of the discipline range from a technical focused and intimately relation between information technology (IT) and information systems on the one hand (Benbasat and Zmud, 2003), to a broad perspective of "systems in organizations" on the other (Alter, 2003).

Many contributions have emphasized the multidisciplinary character of IS, but many simultaneously have stated the lack of concrete theoretical foundations, theories or concepts that are accepted by the majority of IS researchers. It is argued that the IS discipline is inherently pluralistic with a diversity in problems researched (Bakshi and Krishna, 2007). Although IT is generally accepted as a major element in IS (e.g., Benbasat and Zmud, 2003; Orlikowski and Iacono, 2001), there are claims that IS is fundamentally 
rooted more in management than in computing or IT (Dickson et al., 1982). Recent debates focused on whether IS is primarily linked and part of the business discipline or if the IS discipline itself can complement other domains, like healthcare or public administration. This ongoing discussion reiterates the key problem of identifying the core concepts and themes of the IS discipline. In addition, regularly the research outputs of the IS community are also questioned both by academia and practitioners, and frequently considered less rigorous, with limited relevance.

Despite the extensive debate and many valuable contributions over the last years, obviously there is a need to continue the work on clarifying core concepts of IS as a discipline. It could be argued that the lack of a clear identity is due to the relatively immaturity of the discipline; however after more than four decades of research these arguments seem to lose validity. We acknowledge that an ongoing discussion about essential foundations and concepts is required and, due to the dynamics of the discipline, periodical reviews are essential.

The limits in the overall foundation of IS and lack of clear concepts have serious implications for IS departments and individual researchers as well as the discipline as a whole. For instance, the lack of a distinct identity results in an imprecise research agenda that distracts the attention from investigating critical research questions. This in turn reduces the ability to make significant contributions to the body of knowledge in IS. Researchers and IS departments are forced to argue continuously about the value, rigor and relevancy of their research. This in turn affects the capacity of the discipline to acquire adequate funding, resourcing and furthermore to design attractive study programs. IS researchers face increasing difficulties to compete for research funding, combined with a general decline in collaborative research activity with industry. The continuation and indeed its acceleration of the crisis is clearly visible, that despite the increasing importance of IT in general, at the same time IS courses are disappearing, significant research activities led by IS researchers are rarely appearing and even IS departments are at risk.

Simultaneously with the discussion about the identity of the IS discipline, there is an ongoing debate on essential skills and capabilities of IS graduates and the profile of IS courses. There are arguments that computing graduates are better qualified for technical oriented jobs, with IS graduates often lacking essential technical and programming capabilities. At the same time, IS graduates find it difficult to compete with the high number of business graduates. The debate along the IS curriculum and course development is echoed in discussions in numerous IS departments and among faculty. Schools with traditional computing degree programs are incorporating business aspects and developing variations in many of their IT programs (Laundry et al., 2003). At the same time, business schools are extending their program portfolio and are offering various types of management information systems courses and courses with a computing and IT element. Many attempts have been made to develop frameworks for information systems (e.g., Bacon and Fitzgerald, 2001) and to provide references for curricula. However, as yet, universities and academics are facing the challenge of deciding the direction and content of IS study programs.

For an area with a multidisciplinary character we accept that different programs with an emphasis of selected aspects of IS are essential and necessary (e.g., Benbasat and 
Zmud, 2003; DeSanctis, 2003; Galliers, 2003; Klein and Hirschheim, 2003; Lyytinen and King, 2004; Orlikowski and Lacono, 2001; Robey, 2003; Straub, 2003). However, as frequent discussions among IS faculty about the core elements and subjects of IS degrees indicate, there is a certain level of uncertainty within the discipline. Among IS academics, there are various views on the aim and the profile of IS study programs. It is argued, that IS degrees should provide a broad business and real world perspective, strong analytical and critical thinking skills, interpersonal communication and team skills as well as core knowledge of IS. These skills should be combined with a solid methodological foundation in design and implementation of information technology solutions that enhance organizational performance (Disterer et al., 2003; Gorgone et al. 2002a). Furthermore, many academics and practitioners within the IS discipline argue for a solid knowledge and practice in software engineering, programming and computing technology. Following some debates, as for instance on the mailing list "IS World", it seems that the IS curriculum should include many (if not all) related subjects ranging from business and information system strategy to management and marketing, organizational concepts, modelling and information systems architecture, programming, mathematics, statistics and operations research as well as computing, networking and Information and Communication Technologies (ICT). In addition, the complaints often reported on a regular basis from practitioners are that university educators do not prepare their students adequately for the demands of the real professional career focused world.

Addressing the need for guidance and direction, several reference curricula were developed and are under constant revisions (Topi et al., 2007). Some of the prominent reference curricula related to information systems include the IS 2002: Curriculum Guidelines for Undergraduate Degree Programs in Information Systems (Gorgone et al., 2002a, Gorgone et al., 2002b) and the MSIS 2000: Model Curriculum and Guidelines for Graduate Degree Programs in Information Systems (Gorgone et al., 2000).

In order to contribute to debates on IS curricula, with this paper we recognize the need for different IS perspectives results in diverse study profiles. This paper presents a study investigating the profile of IS and contribute a reference structure for a Business Informatics (BI) study programs, as one example for an IS profile. Complementing the reference curricula such as IS2002 and MISI2000, objective of this paper is to provide guidelines for the faculty in universities to design IS. The results presented in this article are centred on a survey conducted between 2007 and 2008 among academics teaching IS and BI programs. In parallel and subsequent to the survey, the results are reflected by experiences made during a series of meetings and panel discussions among IS experts at the European Conference of IS during 2007 to 2009.

The remainder of this article is structured as follows: In Section 2 we review selected IS curricula. In Section 3 we present our IS evaluation framework and study design, followed by analyzing and presenting our results in Section 4. Before we summarize and conclude our work in Section 6, we present an example of an IS profile related to Business Informatics that was developed during an European curriculum development project. 


\section{Related Work - Selected IS Curricula}

As mentioned above there are several reference curricula present, and thus the work presented in this article can build on almost 30 years of experience in IS curriculum development. Our work combines two most prominent undergraduate and graduate IS curricula which are extended by one important European based referred reference curriculum in BI:

- the model curriculum and guidelines for graduate degree programs in information systems (MSIS 2000) (Gorgone et al., 2000);

- the most recent version of the information systems undergraduate model curriculum (IS 2002) (Gorgone et al., 2002a) and

- the recommendation for business informatics at universities (BI recommendation) (Gesellschaft für Informatik, 2003).

The model curricula MSIS2000 and the IS2002 are frequently mentioned in many discussions and are the most comprehensive IS reference curricula. The curricula accumulate long experience in IS curriculum development and provide a coherent structure for a study program in information systems. The curricula are detailed description of reference study programs and contents, which explicitly combine three major disciplines: computer science, software engineering, and information systems. Historically the model curricula are primarily based on the educational system and degree structures common to the USA and Canada, and as such the curricula are sometimes criticized with limited acceptance, use and adaptability outside of North America. Nonetheless, due to their relevance and level of detail, the model curricula are relevant and appropriate for our study, in order to build our study and evaluation framework.

In our work we refer to the IS 2002 model curriculum as the most prominent version for an undergraduate IS curriculum; although the current version is currently under review by a joint ACM/AIS task force (Topi et al., 2007). The IS 2002 includes detailed course descriptions and prescriptive advice on how to offer an IS undergraduate degree program. On a master level, the MSIS 2000 model curriculum was published by ACM and AIS as a guideline for master degree programs in information systems. The curriculum is designed to accommodate students from a wide variety of backgrounds. It considers a set of interrelated building blocks including foundational skills, core subjects, integration subjects, and career tracks. Emphasizing on career development skills, the curriculum includes: oral, written, and presentation skills; people and business skills; ethics and professionalism.

The two level educational structures underlying the curricula proved to be of advantage for our study, as driven by the so called "Bologna Agreement" many European universities are restructuring their study programs towards a 2-phase curriculum with Bachelor and Master Degrees.

The third curricula we used, the recommendation for Business Informatics (BI), is issued by the German Society for Informatics and the Association of University Professors of Management, Germany. It is aimed at providing common directions for education in business informatics at universities. In contrast to the MSIS curriculum, which provides 
a detailed recommendation for a curriculum, the $\mathrm{BI}$ recommendation is intended as a guideline and is focused on key qualifications and core subjects to be taught.

\section{Study Design and IS Evaluation Framework}

The work presented in this article represents results from a survey and a study that was conducted between 2007 and 2009. An initial survey in 2007 was subsequently followed by meetings and interviews with domain experts in order to investigate the perception of academics in IS. Complementing our results we were involved in a major curriculum development project in Europe. The work presented in this article is subsequent to an earlier study, in which we investigated differences between IS and BI study programs (Helfert, 2008). In order to avail of the rich experience in IS curricula, we amalgamated the three prominent curriculum guidelines described above and developed an evaluation framework. In order to cluster subjects and to match the consolidated list of taught subjects, we customized the initial framework in an iterative process involving expert opinion from 10 academics from different countries. The framework was also discussed and refined at international conferences (e.g., Helfert, 2007; Helfert and Duncan, 2006, Helfert and Duncan, 2007).

The structure follows the proposed curriculum building blocks in the MSIS curriculum. However, in order to accommodate particular subjects taught in some study programs, we added subject blocks of mathematics and logic, structural science, legislation, and economics, and business engineering. We also included taught business subjects, for example logistics, procurement, and supply chain management. The list of career electives and domain specific subjects presented here illustrates no more than some of the possible topics. The final framework is presented in Table 1.

Based on the framework and the principle building blocks we designed a questionnaire (see Appendix B) comprising of five main questions. With the first question participants can optionally provide name, email and institutional details. Question two asks about the levels of degree programs offered by the university (e.g., Bachelor or Master programs). Question 3 provides some insight into the responsibilities for the program, as well as the number of semesters for completion and the number of students enrolled in the program. Question 4 aimed to enquire about the general direction of the program, whether a reference curriculum was used in the design of the program, the main focus and the prerequisites.

The main question of the questionnaire is question 5 , in which we used a constantsum allocation for the various subjects. The respondents had to allocate and distribute 100 points to 20 subjects. As outlined in Fig. 1, for our web based survey we programmed a constant-sum question type using "slider bars". The question represents building blocks and topics presented in the framework above summarizing 20 topics that represent common aspects taught in business informatics and information systems degrees. Participants are asked to indicate the relative importance of the topics by distributing 100 available points among the sliders. 
Table 1

Framework for information systems study programs

\begin{tabular}{|c|c|c|c|c|}
\hline $\begin{array}{l}\text { Fundamentals } \\
\text { in Informatics }\end{array}$ & $\begin{array}{l}\text { Business and } \\
\text { Economics }\end{array}$ & $\begin{array}{l}\text { Information } \\
\text { Systems }\end{array}$ & $\begin{array}{l}\text { Integration and } \\
\text { Enterprise } \\
\text { Engineering }\end{array}$ & $\begin{array}{l}\text { Domain-specific } \\
\text { career electives } \\
\text { (representative) }\end{array}$ \\
\hline $\begin{array}{l}\text { Information and } \\
\text { Communication } \\
\text { Technology } \\
\text { (Hardware, } \\
\text { Software, } \\
\text { Networks and } \\
\text { Communication } \\
\text { Technology) } \\
\text { Programming } \\
\text { and Algorithms, } \\
\text { Data and Object } \\
\text { Structures } \\
\text { Mathematics } \\
\text { and Logic (Analy- } \\
\text { sis, } \\
\text { linear Algebra, } \\
\text { Numeric, Logic) } \\
\text { Structural } \\
\text { Science } \\
\text { (Decision theory } \\
\text { and methods for } \\
\text { strategic } \\
\text { decision making } \\
\text { (e.g., risk analysis), } \\
\text { statistics and } \\
\text { quantitative } \\
\text { models and } \\
\text { methods, } \\
\text { operations } \\
\text { research, } \\
\text { computational } \\
\text { modeling and } \\
\text { simulation) }\end{array}$ & $\begin{array}{l}\text { Accounting and } \\
\text { Financing } \\
\text { Marketing, } \\
\text { Production, } \\
\text { Procurement, } \\
\text { Logistics, } \\
\text { Supply Chain } \\
\text { Management } \\
\text { Organization, } \\
\text { human } \\
\text { resources and } \\
\text { corporate } \\
\text { management } \\
\text { Legislation and } \\
\text { Economics }\end{array}$ & $\begin{array}{l}\text { Fundamentals of } \\
\text { Information Systems } \\
\text { (types of IS, IS } \\
\text { industry, } \\
\text { IS relevant } \\
\text { legal frameworks, } \\
\text { Management and IS) } \\
\text { Principles of } \\
\text { Business } \\
\text { Information Systems } \\
\text { (principles of } \\
\text { functional and } \\
\text { process orientation } \\
\text { and industry } \\
\text { solutions) } \\
\text { Data Engineering } \\
\text { (Data modeling and } \\
\text { management, } \\
\text { knowledge } \\
\text { engineering and } \\
\text { business } \\
\text { intelligence) } \\
\text { System and } \\
\text { Software } \\
\text { Engineering } \\
\text { (analysis, modeling } \\
\text { and design) } \\
\text { Managing Data } \\
\text { Communication and } \\
\text { Networking } \\
\text { Information } \\
\text { Management } \\
\text { (Information, } \\
\text { Knowledge and } \\
\text { People, Project and } \\
\text { Change } \\
\text { Management, } \\
\text { IS/IT Policy and } \\
\text { Strategy, Ethics and } \\
\text { Privacy) }\end{array}$ & $\begin{array}{l}\text { Business } \\
\text { Engineering and } \\
\text { Information } \\
\text { System } \\
\text { Architecture } \\
\text { Integrating } \\
\text { Information } \\
\text { System } \\
\text { Functions, } \\
\text { Processes } \\
\text { and Data } \\
\text { Integrating } \\
\text { Information } \\
\text { System } \\
\text { Technologies } \\
\text { and Systems }\end{array}$ & $\begin{array}{l}\text { Academia and } \\
\text { Research } \\
\text { Biochemistry and } \\
\text { Molecular Biology } \\
\text { Consulting } \\
\text { Consumer Health } \\
\text { Information } \\
\text { Customer } \\
\text { Relationship } \\
\text { Management } \\
\text { Data Warehousing } \\
\text { Decision Making } \\
\text { E-Government } \\
\text { Electronic } \\
\text { Commerce } \\
\text { Electronic } \\
\text { Publishing } \\
\text { Environmental } \\
\text { management } \\
\text { Financing and } \\
\text { Banking } \\
\text { Healthcare } \\
\text { Information } \\
\text { Human Factors } \\
\text { Insurance } \\
\text { Management } \\
\text { Knowledge } \\
\text { Management } \\
\text { Library Services } \\
\text { Multimedia } \\
\text { Technologies } \\
\text { Research Libraries } \\
\text { Techniques of } \\
\text { IT-consulting } \\
\text { Technology } \\
\text { Management }\end{array}$ \\
\hline
\end{tabular}




\begin{tabular}{|c|c|c|c|}
\hline Point Allocation & , & & - 35 \\
\hline $\begin{array}{l}\text { Information and Communication } \\
\text { Technology }\end{array}$ & $\longrightarrow \quad \cdot 10$ & Programming and Algorithms & $\Leftrightarrow$ \\
\hline Mathematics and Logic & $\longrightarrow, 15$ & Structural Science & $\theta \quad, 0$ \\
\hline Accounting and Finance & $\phi \quad, 0$ & $\begin{array}{l}\text { Marketing, Production, } \\
\text { Procurement, Logistics }\end{array}$ & $\diamond \quad, 0$ \\
\hline $\begin{array}{l}\text { Organization, human resource } \\
\text { and corporate management }\end{array}$ & $\nabla \quad, 0$ & Legislation and legal Regulations & . 0 \\
\hline $\begin{array}{l}\text { Fundamentals of Information } \\
\text { Systems }\end{array}$ & $\diamond \quad, 0$ & $\begin{array}{l}\text { Principals of Business } \\
\text { Informatics }\end{array}$ & $\longrightarrow \quad .5$ \\
\hline Data Engineering & $\Rightarrow 20$ & $\begin{array}{l}\text { System and Software } \\
\text { Engineering }\end{array}$ & 10 \\
\hline $\begin{array}{l}\text { Managing Data Communication } \\
\text { and Networking }\end{array}$ & $\Longrightarrow \quad, 5$ & Information Management & $\phi \quad, 0$ \\
\hline $\begin{array}{l}\text { Business Engineering and } \\
\text { Information System } \\
\text { Architecture } \\
\end{array}$ & $\diamond \quad, 0$ & $\begin{array}{l}\text { Integrating Information System } \\
\text { Functions, Processes and Data }\end{array}$ & $\phi \quad, 0$ \\
\hline $\begin{array}{l}\text { Integrating Information System } \\
\text { Technology and Systems }\end{array}$ & $\longrightarrow \quad, 10$ & Interpersonal skills & $\diamond \quad, 0$ \\
\hline Teamwork and Leadership & $\diamond \quad, 0$ & Communication skills & 10 \\
\hline
\end{tabular}

Fig. 1. Framework to evaluate topics in Business Informatics.

The survey was provided by means of an online (web based) questionnaire. Using a contact list from our previous study (Helfert, 2007) containing 165 relevant contacts, an invitation to participate in our survey was sent out directly to academics and program coordinators involved in business informatics and information systems programs in the UK, Ireland and the German-speaking area. We explicitly focused on European contacts in order to complement the often North American perspective in IS curriculum development. However in order to extend our data sample, we also distributed an email inviting for participation to the email distribution lists on "IS World" and to the German Business Informatics community ("WI List"). We described the survey and its objectives as well as context within the invitation letter and on the survey web page. The survey was carried out in March and April 2007, with a subsequent data analysis phase.

\section{Results and Analysis}

Subsequent to the data collection we carried out a descriptive data analysis. In order to describe the results in this section we first illustrate the broader context in which IS degrees are offered, before we move on to a closer examination of the content of the degree programs. In total we received 81 responses of which two of the responses indicated that they do not offer any related study program and two responses was incomplete. Subsequently we excluded the responses from the further analysis resulting in 77 valid and complete responses. Allowing for multi degree offerings, 72 respondents indicated to of- 


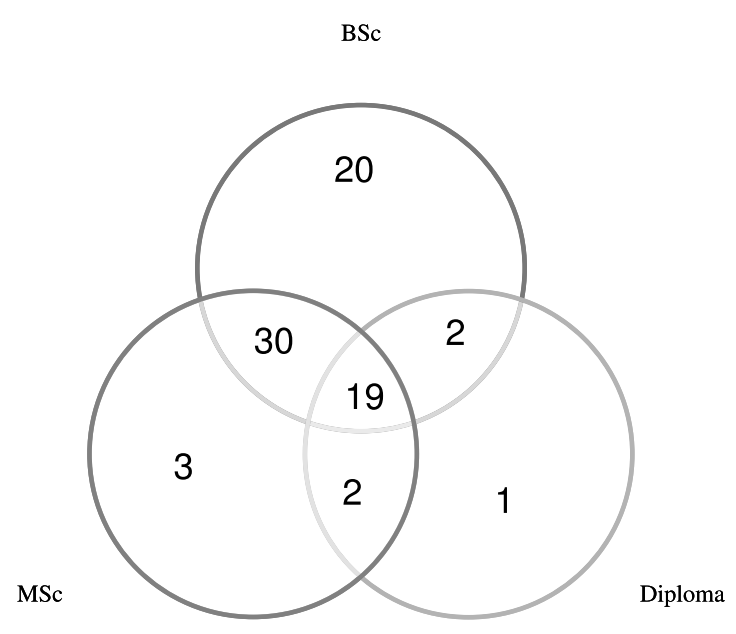

Fig. 2. Overview study programs.

Table 2

Degree - faculty allocation

\begin{tabular}{lll}
\hline & Bachelor & Master \\
\hline Business & $60.0 \%$ & $36.8 \%$ \\
Computing & $30.0 \%$ & $26.3 \%$ \\
IS / Business Informatics & $10.0 \%$ & $36.8 \%$ \\
\hline
\end{tabular}

fer a Bachelor Degree, 54 a Master, 25 a Diploma and 10 another degree (mostly PhD). The distribution and overlap between degree programs can be observed in Fig. 2.

On closer examination, the diploma courses are offered in continental Europe and are equivalent to a Master qualification. Therefore we combine Master and Diploma into one category $(N=57)$ for the subsequent analyses. As stated in the questionnaire, we only considered the highest degree for allocating topics, resulting that we had $N=20$ respondents for Bachelor level.

Regarding the Faculty to which the programs belong, we observe the following data (Table 2). 36.6 percent of respondents who offered a Master degree have their own IS/BI department, in contrast to only 10 percent of Bachelor degrees, indicating that many bachelor degrees are offered within a broader business and computing department. This underpins our earlier discussion, that computing and business departments often offer variations of IS degrees.

\section{Number of Students and Study Duration}

Regarding the number of students enrolled we observed the following result. Three universities stated that they enrolled 500 or more students (one university from China with 
2000 students, one university from the USA with 800, and one university from Slovenia with 500 students). These student numbers differ significant, compared with other Universities with a minimum of 10 students and a Mean of 119 students (Standard Dev. 256). Therefore we decided not to consider the 3 universities when analyzing the enrolment numbers in the following. 5 Universities did not provide any figures regarding enrolment, thus we considered 69 valid responses regarding the number of students enrolled in the program, as demonstrated in the Table 3 and Fig. 3.

Regarding the future trend of student numbers, 40 percent expect stability in the number of students, whereas 30 percent expect either an increase or decrease in the numbers (Table 4).

The duration of the study programs (Fig. 4) differ from bachelor degree with a mean of 6.94 semesters (standard dev. 1.589) to 5.76 (standard dev. 2.38) semesters on a master level. The relative high duration on a Master level might be the result of integrated or interlinked courses between bachelor and master level.

Table 3

Student numbers

\begin{tabular}{llll}
\hline & Bachelor & Master & Overall \\
\hline Mean & 53.61 & 85.0 & 76.81 \\
Std. deviation & 39.677 & 82.31 & 74.619 \\
N & 18 & 51 & 69
\end{tabular}

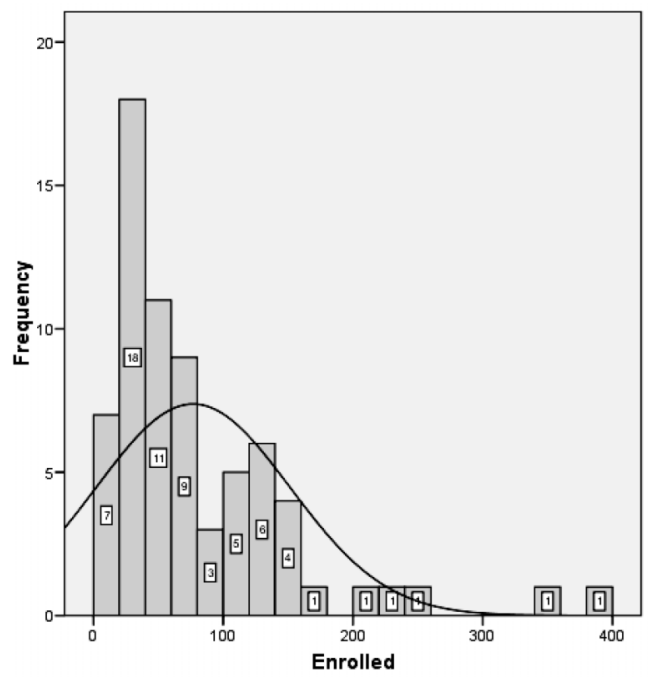

Fig. 3. Number of students enrolled in programs. 
Table 4

Future trend of student numbers

\begin{tabular}{llll}
\hline & Bachelor & Master & Overall \\
\hline Stable & $45.0 \%$ & $38.6 \%$ & $40.3 \%$ \\
Increasing & $30.0 \%$ & $29.8 \%$ & $29.9 \%$ \\
Decreasing & $25.0 \%$ & $31.6 \%$ & $29.9 \%$ \\
\hline
\end{tabular}

BSc

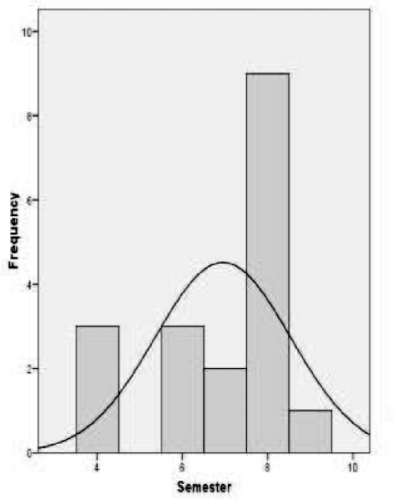

MSc

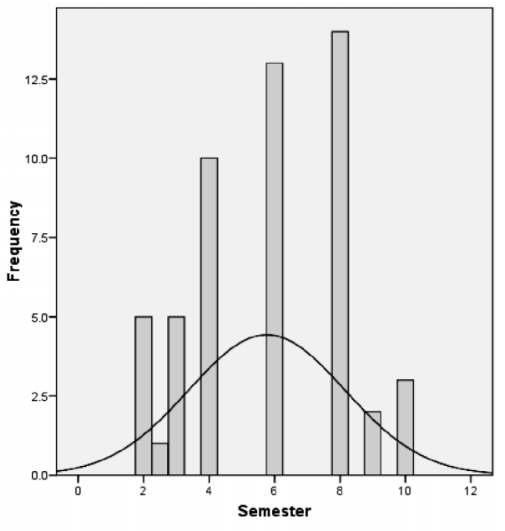

Fig. 4. Duration of study programs.

\section{Curricula Development and Content}

When analyzing the general design of the study programs and curricula development, only 30 percent used the MSIS \& IS2002 as orientation to develop their study programs. Most Universities adapted similar study programs or used industry demands and expertise within the department or university as guidelines to develop a study program (Table 5).

In order to confirm our initial categorization in Table 1 , we conducted a factor analysis. The best result identified 6 factors, however with different accentuation of subjects (see Table A1 in Appendix A) and thus were inconclusive. For this reason we decided not to cluster topics accordingly and to analyze the content of the study programs in detail along each individual subject.

Table 5

Study program guidance

\begin{tabular}{llll}
\hline Similar & MSIS \& IS2002 & Industry & Expertise \\
\hline $45.5 \%$ & $29.9 \%$ & $66.2 \%$ & $87.0 \%$ \\
\hline
\end{tabular}


Table 6

Descriptive statistic of IS/BI topics

\begin{tabular}{|c|c|c|c|c|}
\hline & $\mathrm{N}$ & Maximum & Mean & St. Deviation \\
\hline Information and Communication Technology & 77 & 20 & 7.44 & 5.048 \\
\hline Information Management & 77 & 20 & 6.68 & 3.885 \\
\hline Fundamentals of Information Systems & 77 & 20 & 6.66 & 3.882 \\
\hline Integrating Information System Technologies and Systems & 77 & 20 & 5.88 & 4.174 \\
\hline Programming and Algorithms, Data and Object Structures & 77 & 20 & 5.86 & 5.039 \\
\hline Integrating Information System Functions, Processes and Data & 77 & 18 & 5.86 & 4.119 \\
\hline Business Engineering and Information System Architecture & 77 & 15 & 5.55 & 3.578 \\
\hline Principles of Business Information Systems & 77 & 20 & 5.45 & 4.038 \\
\hline System and Software Engineering & 77 & 20 & 5.31 & 4.212 \\
\hline Organization, human resources and corporate management & 77 & 20 & 5.05 & 3.741 \\
\hline Teamwork & 77 & 12 & 4.96 & 3.114 \\
\hline Communication Skills & 77 & 15 & 4.44 & 2.945 \\
\hline Managing Data Communication and Networking & 77 & 12 & 4.43 & 3.067 \\
\hline Interpersonal Skills & 77 & 10 & 4.29 & 2.6 \\
\hline \multicolumn{5}{|l|}{ Marketing, Production, Procurement, Logistics, Supply Chain } \\
\hline Management & 77 & 14 & 4.17 & 3.526 \\
\hline Data Engineering & 77 & 12 & 4.09 & 3.317 \\
\hline Accounting and Financing & 77 & 12 & 3.77 & 3.207 \\
\hline Mathematics and Logic & 77 & 10 & 3.3 & 2.824 \\
\hline Legislation and Economics & 77 & 7 & 2.4 & 2.085 \\
\hline Structural Science & 77 & 6 & 0.86 & 1.57 \\
\hline
\end{tabular}

Table 6 describes our results regarding the distribution of topics. With a mean of 7.44 ICT was identified as the most important topic, followed by Information Management and Fundamentals of IS. Legislation and structural Science was identified as least important. In Appendix, Table A2 shows the analysis regarding faculties (Business, Computing, and Information Systems) with no significant difference between the faculties and importance of topics. Also an analysis regarding the degree level of Bachelor or Master did not reveal any significant differences in the importance of topics either (Appendix, A3).

The most interesting result is revealed when comparing the focus of the different degrees. We analyzed an IT, an IS as well as a Business focus of the degrees. Figure 5 shows the profile diagram of the three foci. IT oriented degrees show an emphasis on ICT, Programming and Mathematics with a slight shift to System and Data Engineering. Comparing Business and IS degrees, it appears that both streams are characterize by a similar thematic profile. This indeed demonstrates the identity problem of IS lacking a clear thematic profile that is unique to the discipline. Details of our results regarding the thematic focus can be found in the Appendix (Tables A4-A6), which includes also details of analyzing ICT and Programming (Table A7). We analyzed combinations between study foci from pre-requisites and main foci from the study program. Notable hereby, Business and IS degrees also contain a considerable emphasis on ICT and Programming. 


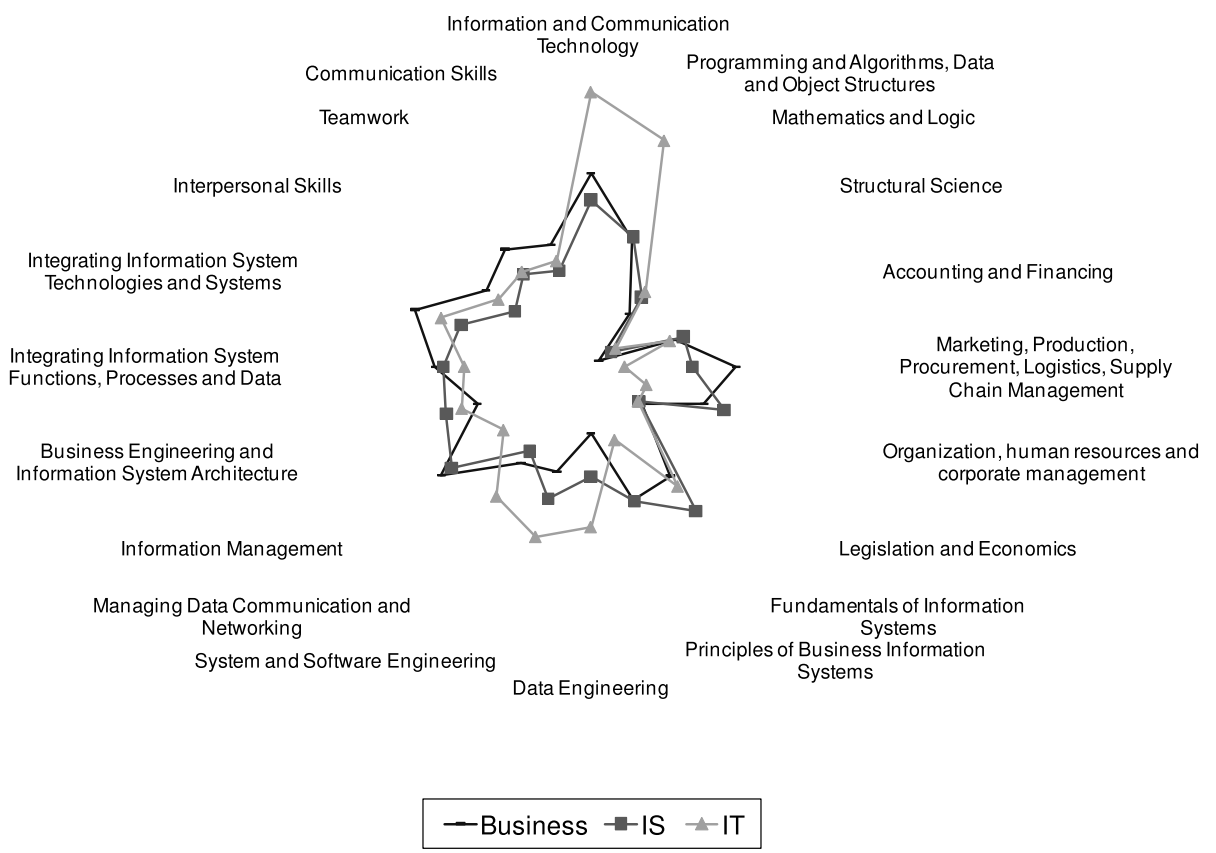

Fig. 5. Thematic profile considering the focus of the programs.

In parallel to the empirical study we reflected our results by the means of expert discussions and feedback. In 2006 we started with a panel at the 14th European Conference on Information Systems (ECIS 06) discussing grand challenges in common Europe concerning education and research in business informatics. The discussion was focused on the importance of core subjects, teaching mode, and research topics within the discipline from a management, information systems, and informatics perspective. The discussion showed that education in information systems is very diverse, with different streams in information systems; on the one hand a technology, engineering and method orientated perspective and on the other hand a business and management orientated focus. Noteworthy is the emphasis on engineering principles in business informatics degrees in contrast to managerial oriented IS degrees. Although common in continental European countries, the business informatics degrees are still relatively rare in Anglophone countries.

At the 16th European Conference on Information Systems (ECIS 08) a meeting with academics from various countries was held discussing aspects of business informatics. The discussion reiterated the engineering characteristics of business informatics in contrast to the managerial oriented stream of information systems. From the discussion it appeared that engineering topics, including mathematics and structural science are important and the characteristic element of many IS degrees in continental Europe, often described as "Business Informatics".

In 2009, at the 17th European Conference on Information Systems (ECIS 09) we continued this discussion with participants from previous meetings and an extended mem- 
bership. The discussion emphasized the need for characteristics of IS study programs and demonstrated the variety of different IS profiles. The participants agreed that there are different streams of IS, with business informatics one that is characterized by engineering principles. The discussion underpinned the necessity of this study and the work on profiles of IS study programs, recognizing distinct IS profiles. In our work we identified Business Informatic as one distinct IS profile. A reference profile for Business Informatics will be described in the following section.

\section{A Reference Profile for Business Informatics}

Simultaneously to this study we were also involved in a European Curriculum project, the BIN-Net: business informatics Network in Common Europe. The main results and experiences from this project were presented and discussed with academics during the meeting at the 17th European Conference on Information Systems (ECIS 09). The project has been funded under the European Erasmus scheme within the Socrates Program. It involved 10 partnering universities in eight European countries. The developed curriculum structure of this program is seen as characteristic for many continental European study programs in business informatics and together with our study can provide a reference profile for business informatics.

As a common master degree in business informatics, the program's focus is on the intersection between business informatics, computer science and business. As such, business informatics provides the distinct element of the curriculum which complements the disciplines of informatics and business. With an interdisciplinary focus the project is a direct response to the changing requirements for graduates in the area of information technology and information systems. In particular the graduates of this Master program should gain knowledge in

- design and implementation of organizational concepts;

- development and implementation of operational information systems;

- sound knowledge in applied Computer Science;

- improved social and cultural skills through mobility;

- language skills gained during the exchange in partner universities;

- expansion of the knowledge in the development of formal models;

- completion of the basic understanding of technical, methodological and economic concepts;

- further interdisciplinary specialization in the related fields (business Administration, Economics, Computer Science, and Sociology);

- promotion of a scientific approach to solve problems related to business informatics.

As a European project, the program also aims to facilitate teachers and student mobility. In order to improve international transparency and recognition the curriculum structure is modular and all modules are valuated within the European Credit Transfer System (ECTS). Each partner institution is required to recognize the common degree and the ECTS system. 


\begin{tabular}{|c|c|c|c|c|c|}
\hline $\begin{array}{l}\text { 15t Semester } \\
\text { 30 ECTS }\end{array}$ & $\begin{array}{l}\text { Structural } \\
\text { Sciences }\end{array}$ & $\begin{array}{l}\text { Business } \\
\text { Sciences/ } \\
\text { Economics }\end{array}$ & $\begin{array}{l}\text { Business } \\
\text { Informatics }\end{array}$ & $\begin{array}{l}\text { Information } \\
\text { Management }\end{array}$ & Elective \\
\hline $\begin{array}{l}2^{\text {nd }} \text { Semester } \\
\text { 30 ECTS }\end{array}$ & $\begin{array}{c}\text { Sp. Elective } 1 \\
\text { Module } 1\end{array}$ & $\begin{array}{c}\text { Sp. Elective } 1 \\
\text { Module } 2\end{array}$ & $\begin{array}{l}\text { Business } \\
\text { Informatics }\end{array}$ & $\begin{array}{c}\text { Sp. Elective } 2 \\
\text { Module } 1\end{array}$ & $\begin{array}{c}\text { Sp. Elective } 2 \\
\text { Module } 2\end{array}$ \\
\hline $\begin{array}{l}3^{\text {tid Semester }} \\
30 \text { ECTS }\end{array}$ & $\begin{array}{c}\text { Sp. Elective } 1 \\
\text { Module } 3\end{array}$ & $\begin{array}{c}\text { Sp. Elective } 1 \\
\text { Module } 4\end{array}$ & $\begin{array}{c}\text { Master Thesis } \\
\text { Seminar }\end{array}$ & $\begin{array}{c}\text { Sp. Elective } 2 \\
\text { Module } 3\end{array}$ & $\begin{array}{c}\text { Sp. Elective } 2 \\
\text { Module } 4\end{array}$ \\
\hline $\begin{array}{l}4^{4^{\text {th }} \text { Semester }} \\
30 \text { ECTS }\end{array}$ & \multicolumn{5}{|c|}{ Master Thesis } \\
\hline
\end{tabular}

Fig. 6. Common curriculum structure.

The various subjects in business informatics are structured along a common curriculum structure, which is illustrated in Fig. 6. The curriculum has a modular structure consisting of four semesters. Each "module block" accounts for 5 ECTS and addresses a certain subject of study, which includes courses in the area of Structural Sciences, Business Sciences/Economics, Information Management, Business Informatics as well as a set of elective subjects. Elective subjects include for instance Supply Chan Management, Knowledge Engineering, Business Process Management, Organizations, Technologies and E-Commerce, Knowledge Engineering, Business Process Management, Introduction to the information society, Agents in E-Commerce, Human Factors in Information Systems, Advanced Technologies Supporting Banking/Financial Sector, and Knowledge Management.

The details of each module are described in agreed module descriptors which specify the course type, its content, learning objectives and assessment approach together with the ECTS valuation. Types of courses include lectures, tutorials, practical training, proseminars and seminars. The total degree comprises 120 ECTS credits with 90 ECTS accounted for taught subjects and 30 ECTS credits for a practical and research oriented project (master thesis).

\section{Conclusion and Summary}

The work presented in this article is the continuation of an earlier study, in which we investigated differences between IS and BI study programs (Helfert, 2008). We developed a framework for structuring information systems study programs and characterized some of the differences in study programs. With this work we detailed the topics and exemplify a business informatics study profile. The results from this study are based on a survey and workshops with domain exerts, both from academia and practice. The descriptive results from the survey were presented, and show the diversity of study programs, both on master and bachelor level. Regarding the content, our results demonstrated the lack of a clear identity for IS programs. We also showed that the adoption of standard reference curricula, in particular the MSIS \& IS2002 is limited notably outside North America. Most curricula developments are based on industry demand or similar programs in other universities. In addition to the results from our survey we conducted several workshops and discussions at the European Conference on Information Systems, which underpinned our findings. 
We provided a study profile for business informatics aiming to guide curriculum developments. This was developed within a European project representing a continental European approach to IS. The engineering penetration throughout the program is seen as an important characteristic for business informatics programs, which differentiates the program from management oriented information systems degrees. Therefore the business informatics approach appears to us not only to be innovative with regard to its interdisciplinary character, but moreover the engineering perspective and practical experiences equip graduates with required capabilities.

The emphasis on engineering principles, in addition to the subjects of business, informatics, and information systems should facilitate an analytical and integrated approach. Indeed, the focus on engineering principles in business informatics can play an important role in future education programs. In this context, business informatics (and others) can complement the management-orientated stream of an information systems discipline, which often focuses on business and management aspects.

\section{References}

Alter, S. (2003). Sidestepping the IT artifact, scrapping the IS silo, and laying claim to 'Systems in Organizations. Communications of the AIS, 12(30), 494-526.

Bacon, J., Fitzgerald, B. (2001). A systemic framework for the field of information systems. Data Base, 32(2), 46-67.

Bakshi, S., Krishna, S. (2007). Crisis in the information system discipline: A reflection. In: 18 Australasian Conference on Information Systems. Toowoomba, 132-141.

Benbasat, I., Zmud, R. (2003). The identity crisis within the IS discipline: Defining and communicating the discipline core properties. MIS Quarterly, 27(2), 183-194.

DeSanctis, G. (2003). The social life of information systems research: A response to Benbasat and Zmud's call for returning to the IT artifact. Journal of the Association for Information Systems, 4(7), 360-376.

Disterer, G., Fels, F., Hausotter, A. (Eds). (2003). Taschenbuch der wirtschaftsinformatik. Paperback of Business Informatics, 2nd edn. Carl Hanser Verlag, München, Wien.

Galliers, R. (2003). Change as crisis or growth? Toward a trans-disciplinary view of information systems as a field of study: A response to Benbasat and Zmud's call for returning to the IT artifact. Journal of the Association for Information Systems, 4(6), 337-351.

Gesellschaft für Informatik (Ed.) (2003). Rahmenempfehlung für die universitätsausbildung in wirtschaftsinformatik. Guidelines for the education in business informatics at universities. Informatik Spektrum, 26(2), $108-113$.

Gorgone, J., Davis, G., Valacich., J, Topi H., Feinstein, D., Longenecker, H. (2002a). IS 2002: Model Curriculum and Guidelines for Undergraduate Degree Programs in Information Systems. Association for Information Systems.

Gorgone, J., Feinstein, D., Longenecker, H., Topi, H., Valacich, J., Davis, G. (2002b). Undergraduate information systems model curriculum update - IS 2002. In: Proceedings of the Eighth Americas Conference on Information Systems.

Gorgone, J., Gray, P., Feinstein, D., Kasper, G., Luftman, J., Stohr, E. et al. (2000). Model curriculum and guidelines for graduate degree programs in information systems. Communication of the Association for Information Systems, 3(1), 1-51.

Helfert, M. (2007). Teaching information quality skills in a business informatics program. In: Proceedings of the MIT Information Quality Industry Symposium. Cambridge, Massachusetts, USA, 908-912.

Helfert, M., Duncan, H. (2006). Aspects on information systems curriculum: A study program in business informatics. In: Donnellan, B., Larsen, T., Levine, L., DeGross, J. (Eds.), International Federation for Information Processing (IFIP), Vol. 206. The transfer and diffusion of information technology for organizational resilience. Boston, Springer, 229-237. 
Helfert, M., Duncan, H. (2007). Evaluating information systems and business informatics curriculum. In: Proceedings of International Conference on Computer Systems and Technologies, CompSysTech'07, University of Rousse, Bulgaria.

Helfert, M. (2008) Business informatics: An engineering perspective on information systems. Journal of Information Technology Education, 7, 223-245.

Hirschheim, R., Klein, H.A. (2003). Crisis in the IS field? A critical reflection on the state of the discipline. Journal of the Association for Information Systems, 4(5), 237-293.

Laundry, J.P., Pardue, J.H., Longenecker, H.E., Feinstein, D.F. (2003). A common theme for IT degree programs. Communications of the ACM, 46(11), 117-120.

Lyytinen, K., King, J. (2004). Nothing at the center? Academic legitimacy in the information systems field. Journal of the Association for Information Systems, 5(6), 220-246.

Orlikowski, W., Iacono, C. (2001). Desperately seeking the 'IT' in IT research - A call to theorizing the IT artifact. Information Systems Research, 12(2), 121-134.

Robey, D. (2003). Identity, legitimacy and the dominant research paradigm: An alternative prescription for the IS discipline: A response to Benbasat and Zmud's call for returning to the IT artifact. Journal of the Association for Information Systems, 4(7), 352-359.

Straub, D. (2003). IS research perspectives: A mandate for scholarly debate. Journal of the Association for Information Systems, 4(5), 233-236.

Topi, H., Valacich, J., Kaiser, K., Nunamaker, J., Sipior, J., Vreede, G., Wright, R. (2007). Revisiting the IS model curriculum: Rethinking the approach and the process. Communications of the Association for Information Systems, 20(11), 728-740.

\section{Appendix A}

Table A1. Extraction method: principal component analysis

\begin{tabular}{|c|c|c|c|c|c|c|}
\hline & \multicolumn{6}{|c|}{ Component } \\
\hline & 1 & 2 & 3 & 4 & 5 & 6 \\
\hline DataEngineering & -.614 & & & & & \\
\hline ProgAlgorithms & -.607 & & & & & \\
\hline SystemSoftwareEng & -.585 & & .483 & & & \\
\hline PrinciplesBI & .492 & & & & & .460 \\
\hline IntegrationIT & .487 & & & -.403 & & \\
\hline InformationMng & .483 & & & & & .472 \\
\hline Marketing & & .674 & & & & \\
\hline MathematicsLogic & & .607 & & & & \\
\hline ICT_1 & & -.565 & & .441 & & \\
\hline CommunicationSkills & & .418 & .554 & & & \\
\hline Teamwork & & & .547 & & & \\
\hline BusinessEng & & & .511 & & & \\
\hline ManagingDataComm & & & .463 & & & \\
\hline Accounting & & .430 & & .496 & & \\
\hline FundamentalsIS & & & & .472 & .427 & \\
\hline IntegrationProcesses & .446 & & .425 & -.452 & & \\
\hline StructuralScience & & & & -.449 & .440 & \\
\hline Legislation & & & & & .485 & -.569 \\
\hline InterpersonalSkills & & & & & & -.492 \\
\hline OraganisationHR & .425 & & & & & .458 \\
\hline
\end{tabular}

Extraction method: principal component analysis

6 components extracted 
Table A2. Faculty distribution of topics

\begin{tabular}{|c|c|c|c|c|c|c|c|c|c|}
\hline & \multicolumn{9}{|c|}{ Faculty } \\
\hline & \multicolumn{3}{|l|}{$\mathrm{B}$} & \multicolumn{3}{|l|}{$\mathrm{C}$} & \multicolumn{3}{|l|}{ IS } \\
\hline & Mean & $\mathrm{N}$ & $\begin{array}{l}\text { Std. } \\
\text { deviation }\end{array}$ & Mean & $\mathrm{N}$ & $\begin{array}{l}\text { Std. } \\
\text { deviation }\end{array}$ & Mean & $\mathrm{N}$ & $\begin{array}{l}\text { Std. } \\
\text { deviation }\end{array}$ \\
\hline ICT & 7.18 & 33 & 3.770 & 8.38 & 21 & 6.111 & 6.96 & 23 & 5.677 \\
\hline ProgrammingAlgorithms & 5.15 & 33 & 4.744 & 5.52 & 21 & 4.844 & 7.17 & 23 & 5.565 \\
\hline MathematicsLogic & 3.73 & 33 & 3.044 & 2.90 & 21 & 2.773 & 3.04 & 23 & 2.567 \\
\hline StructuralScience & .58 & 33 & 1.300 & .76 & 21 & 1.700 & 1.35 & 23 & 1.748 \\
\hline Accounting & 4.18 & 33 & 3.254 & 3.52 & 21 & 3.586 & 3.39 & 23 & 2.824 \\
\hline Marketing & 5.15 & 33 & 3.930 & 3.10 & 21 & 3.048 & 3.74 & 23 & 3.048 \\
\hline OraganisationHR & 5.30 & 33 & 3.653 & 5.52 & 21 & 4.823 & 4.26 & 23 & 2.615 \\
\hline Legislation & 2.06 & 33 & 2.179 & 2.48 & 21 & 2.112 & 2.83 & 23 & 1.922 \\
\hline FundamentalsIS & 6.03 & 33 & 2.888 & 7.48 & 21 & 4.946 & 6.83 & 23 & 4.053 \\
\hline PrincipalsofBusinessInformatics & 5.52 & 33 & 3.327 & 6.10 & 21 & 5.137 & 4.78 & 23 & 3.919 \\
\hline DataEngineering & 4.30 & 33 & 3.340 & 3.19 & 21 & 2.977 & 4.61 & 23 & 3.551 \\
\hline SystemSoftwareEngineering & 5.18 & 33 & 3.504 & 5.71 & 21 & 4.900 & 5.13 & 23 & 4.625 \\
\hline ManagingDataCommunication & 5.09 & 33 & 3.126 & 3.81 & 21 & 3.140 & 4.04 & 23 & 2.852 \\
\hline InformationManagement & 6.70 & 33 & 3.771 & 6.90 & 21 & 4.878 & 6.43 & 23 & 3.116 \\
\hline BusinessEngineering & 5.94 & 33 & 3.436 & 4.86 & 21 & 3.745 & 5.61 & 23 & 3.690 \\
\hline IntegrationProcesses & 6.33 & 33 & 4.284 & 5.67 & 21 & 4.374 & 5.35 & 23 & 3.725 \\
\hline IntegrationInformationTechnology & 6.09 & 33 & 4.289 & 5.62 & 21 & 4.748 & 5.83 & 23 & 3.576 \\
\hline InterpersonalSkills & 4.58 & 33 & 2.658 & 4.19 & 21 & 2.482 & 3.96 & 23 & 2.688 \\
\hline Teamwork & 5.12 & 33 & 3.110 & 4.81 & 21 & 3.234 & 4.87 & 23 & 3.138 \\
\hline CommunicationSkills & 5.00 & 33 & 2.958 & 4.05 & 21 & 2.459 & 4.00 & 23 & 3.303 \\
\hline \multicolumn{10}{|c|}{ ICT $=$ Information and Communication Technology } \\
\hline \multicolumn{10}{|c|}{ B = Business Department } \\
\hline \multicolumn{10}{|l|}{$\mathrm{C}=$ Computing Department } \\
\hline \multicolumn{10}{|l|}{ IS = Information Systems Department } \\
\hline
\end{tabular}


Table A3. Comparison between degrees (Bachelor and Master)

\begin{tabular}{|c|c|c|c|c|c|c|}
\hline & \multicolumn{6}{|c|}{ Highest level } \\
\hline & \multicolumn{3}{|l|}{$\mathrm{B}$} & \multicolumn{3}{|l|}{$\mathrm{M}$} \\
\hline & Mean & $\mathrm{N}$ & $\begin{array}{l}\text { Std. } \\
\text { deviation }\end{array}$ & Mean & $\mathrm{N}$ & $\begin{array}{l}\text { Std. } \\
\text { deviation }\end{array}$ \\
\hline ICT & 8.60 & 20 & 5.215 & 7.04 & 57 & 4.971 \\
\hline ProgrammingAlgorithms & 8.15 & 20 & 5.432 & 5.05 & 57 & 4.681 \\
\hline MathematicsLogic & 3.15 & 20 & 2.412 & 3.35 & 57 & 2.973 \\
\hline StructuralScience & .45 & 20 & 1.234 & 1.00 & 57 & 1.658 \\
\hline Accounting & 4.35 & 20 & 3.233 & 3.56 & 57 & 3.202 \\
\hline Marketing & 4.05 & 20 & 3.605 & 4.21 & 57 & 3.529 \\
\hline OraganisationHR & 3.65 & 20 & 2.681 & 5.54 & 57 & 3.951 \\
\hline Legislation & 1.65 & 20 & 2.084 & 2.67 & 57 & 2.038 \\
\hline FundamentalsIS & 6.75 & 20 & 3.259 & 6.63 & 57 & 4.104 \\
\hline PrincipalsofBusinessInformatics & 4.35 & 20 & 2.870 & 5.84 & 57 & 4.329 \\
\hline DataEngineering & 5.20 & 20 & 3.381 & 3.70 & 57 & 3.235 \\
\hline SystemSoftwareEngineering & 5.70 & 20 & 4.305 & 5.18 & 57 & 4.209 \\
\hline ManagingDataCommunication & 6.45 & 20 & 3.663 & 3.72 & 57 & 2.498 \\
\hline InformationManagement & 5.85 & 20 & 3.281 & 6.96 & 57 & 4.062 \\
\hline BusinessEngineering & 5.50 & 20 & 3.547 & 5.56 & 57 & 3.620 \\
\hline IntegrationProcesses & 5.45 & 20 & 3.927 & 6.00 & 57 & 4.209 \\
\hline IntegrationInformationTechnology & 5.65 & 20 & 3.528 & 5.96 & 57 & 4.404 \\
\hline InterpersonalSkills & 4.60 & 20 & 2.981 & 4.18 & 57 & 2.472 \\
\hline Teamwork & 5.05 & 20 & 3.154 & 4.93 & 57 & 3.127 \\
\hline CommunicationSkills & 4.35 & 20 & 3.345 & 4.47 & 57 & 2.823 \\
\hline \multicolumn{7}{|c|}{ ICT $=$ Information and Communication Technology } \\
\hline \multicolumn{7}{|l|}{$\mathrm{B}=$ Bachelor Degree } \\
\hline M = Master Degree & & & & & & \\
\hline
\end{tabular}


Table A4. Main focus technical

\begin{tabular}{llrrl}
\hline & $\mathrm{N}$ & Maximun & Mean & Std. deviation \\
\hline ICT & 8 & 20 & 11.13 & 6.875 \\
ProgrammingAlgorithms & 8 & 20 & 9.63 & 6.610 \\
SystemSoftwareEngineering & 8 & 20 & 7.25 & 5.800 \\
ManagingDataCommunication & 8 & 12 & 6.50 & 3.505 \\
DataEngineering & 8 & 12 & 6.50 & 3.338 \\
IntegrationInformationTechnology & 8 & 12 & 6.38 & 3.739 \\
FundamentalsIS & 8 & 10 & 6.00 & 2.390 \\
BusinessEngineering & 8 & 12 & 5.50 & 3.464 \\
IntegrationProcesses & 8 & 15 & 5.13 & 4.853 \\
Teamwork & 8 & 10 & 4.75 & 3.151 \\
InterpersonalSkills & 8 & 7 & 4.63 & 1.685 \\
CommunicationSkills & 8 & 10 & 4.50 & 2.777 \\
InformationManagement & 8 & 10 & 4.38 & 4.173 \\
MathematicsLogic & 8 & 5 & 3.75 & 1.753 \\
Accounting & 8 & 10 & 3.38 & 3.543 \\
PrincipalsofBusinessInformatics & 8 & 5 & 3.13 & 1.959 \\
Legislation & 8 & 5 & 2.38 & 2.326 \\
OraganisationHR & 8 & 7 & 2.38 & 2.560 \\
Marketing & 8 & 6 & 1.38 & 2.560 \\
StructuralScience & 8 & 5 & 1.25 & 1.753 \\
\hline ICT Information and Commung & & & &
\end{tabular}

ICT = Information and Communication Technology

Table A5. Main focus business

\begin{tabular}{lllll}
\hline & $\mathrm{N}$ & Maximum & Mean & Std. deviation \\
\hline ICT & 17 & 15 & 7.82 & 3.610 \\
IntegrationInformationTechnology & 17 & 20 & 7.47 & 4.951 \\
InformationManagement & 17 & 13 & 7.47 & 3.466 \\
IntegrationProcesses & 17 & 13 & 6.29 & 4.027 \\
Teamwork & 17 & 10 & 5.88 & 2.870 \\
Marketing & 17 & 11 & 5.88 & 3.480 \\
PrincipalsofBusinessInformatics & 17 & 13 & 5.65 & 3.427 \\
FundamentalsIS & 17 & 11 & 5.47 & 2.577 \\
ProgrammingAlgorithms & 17 & 20 & 5.41 & 5.756 \\
InterpersonalSkills & 17 & 10 & 5.24 & 2.635 \\
CommunicationSkills & 17 & 10 & 5.18 & 3.206 \\
BusinessEngineering & 17 & 14 & 4.82 & 4.081 \\
ManagingDataCommunication & 17 & 11 & 4.82 & 2.506 \\
OraganisationHR & 17 & 11 & 4.82 & 2.767 \\
SystemSoftwareEngineering & 17 & 11 & 4.47 & 3.300 \\
Accounting & 17 & 10 & 3.59 & 2.830 \\
DataEngineering & 17 & 7 & 2.71 & 2.779 \\
MathematicsLogic & 17 & 6 & 2.65 & 2.344 \\
Legislation & 17 & 7 & 2.53 & 2.478 \\
StructuralScience & 17 & 3 & .41 & .939 \\
\hline ICT & & & &
\end{tabular}

ICT = Information and Communication Technology 
Table A6. Main focus IS

\begin{tabular}{lllll}
\hline & N & Maximum & Mean & Std. deviation \\
\hline FundamentalsIS & 49 & 20 & 7.22 & 4.327 \\
InformationManagement & 49 & 20 & 6.96 & 3.894 \\
ICT & 49 & 20 & 6.76 & 4.990 \\
BusinessEngineering & 49 & 15 & 6.14 & 3.240 \\
IntegrationProcesses & 49 & 18 & 5.96 & 4.138 \\
PrincipalsofBusinessInformatics & 49 & 20 & 5.73 & 4.377 \\
OraganisationHR & 49 & 20 & 5.67 & 4.059 \\
SystemSoftwareEngineering & 49 & 15 & 5.61 & 4.102 \\
ProgrammingAlgorithms & 49 & 15 & 5.53 & 4.416 \\
IntegrationInformationTechnology & 49 & 20 & 5.51 & 3.852 \\
Teamwork & 49 & 12 & 4.61 & 3.081 \\
DataEngineering & 49 & 10 & 4.43 & 3.227 \\
ManagingDataCommunication & 49 & 12 & 4.22 & 2.995 \\
Marketing & 49 & 14 & 4.10 & 3.460 \\
CommunicationSkills & 49 & 15 & 4.08 & 2.745 \\
Accounting & 49 & 12 & 3.94 & 3.375 \\
InterpersonalSkills & 49 & 10 & 3.80 & 2.458 \\
MathematicsLogic & 49 & 10 & 3.49 & 3.035 \\
Legislation & 49 & 6 & 2.41 & 1.914 \\
StructuralScience & 49 & 6 & 1.00 & 1.732 \\
\hline & & & & \\
\hline
\end{tabular}

IS = Information Systems

ICT = Information and Communication Technology 
Table A7. Analyzing ICT and Programming

\begin{tabular}{|c|c|c|c|c|}
\hline PreRequiste & MainFocus & & ICT & $\begin{array}{l}\text { Programming } \\
\text { algorithms }\end{array}$ \\
\hline \multirow[t]{9}{*}{ Business } & \multirow[t]{3}{*}{ Business } & Mean & 7.91 & 7.00 \\
\hline & & Std. deviation & 3.618 & 6.481 \\
\hline & & $\mathrm{N}$ & 11 & 11 \\
\hline & \multirow[t]{3}{*}{ IS } & Mean & 6.27 & 4.18 \\
\hline & & Std. deviation & 4.628 & 5.793 \\
\hline & & $\mathrm{N}$ & 11 & 11 \\
\hline & \multirow[t]{3}{*}{ IT } & Mean & 5.00 & .00 \\
\hline & & Std. deviation & $\cdot$ & $\cdot$ \\
\hline & & $\mathrm{N}$ & 1 & 1 \\
\hline \multirow[t]{9}{*}{ IS } & \multirow[t]{3}{*}{ Business } & Mean & 8.25 & 3.25 \\
\hline & & Std. deviation & 4.031 & 2.754 \\
\hline & & $\mathrm{N}$ & 4 & 4 \\
\hline & \multirow[t]{3}{*}{ IS } & Mean & 6.80 & 5.53 \\
\hline & & Std. deviation & 5.122 & 4.175 \\
\hline & & $\mathrm{N}$ & 30 & 30 \\
\hline & \multirow[t]{3}{*}{ IT } & Mean & 14.50 & 6.00 \\
\hline & & Std. deviation & .707 & .000 \\
\hline & & $\mathrm{N}$ & 2 & 2 \\
\hline \multirow[t]{9}{*}{ IT } & \multirow[t]{3}{*}{ Business } & Mean & 10.00 & 2.00 \\
\hline & & Std. deviation & $\cdot$ & $\cdot$ \\
\hline & & $\mathrm{N}$ & 1 & 1 \\
\hline & \multirow[t]{3}{*}{ IS } & Mean & 8.40 & 8.00 \\
\hline & & Std. deviation & 6.950 & 2.121 \\
\hline & & $\mathrm{N}$ & 5 & 5 \\
\hline & \multirow[t]{3}{*}{ IT } & Mean & 12.50 & 15.00 \\
\hline & & Std. deviation & 8.660 & 4.082 \\
\hline & & $\mathrm{N}$ & 4 & 4 \\
\hline \multicolumn{5}{|c|}{ ICT = Information and Comunication Technology } \\
\hline \multicolumn{5}{|c|}{ IS = Information Systems } \\
\hline \multicolumn{5}{|c|}{$\mathrm{IT}=$ Information Technology } \\
\hline
\end{tabular}




\section{Appendix B - Online Survey}

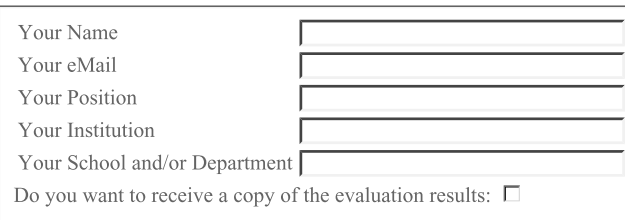

From our initial Web Survey, we have identified your University as offering Degrees in Information Systems or Business Informatics. If your university doesn't currently offer such a degree please press the following button.

The university dosn't offer such a degree I want to leave the survey

Which level(s) of Degree in Information Systems or Business Informatics is offered by your University (only taught programmes)

ГB Bachelor

Fister

Other (please specify)

The following questions relate to the highest level of degree offered in Information Systems or Business Informatics. If your university offers more than one significant different Information Systems or Business Informatics degrees, please select the most representative program

Which Faculty/School is responsible for this programme:

$\Gamma$ Business / Management

$\Gamma$ Computing

- Specific Business Informatics / Information Systems

Other (please specify)

How many semesters does this programme take:

In the last 3 years (or less if the programme is recent), how many students are on average are enrolled in this programme each year: With a trend: Stable $\quad \nabla$ 


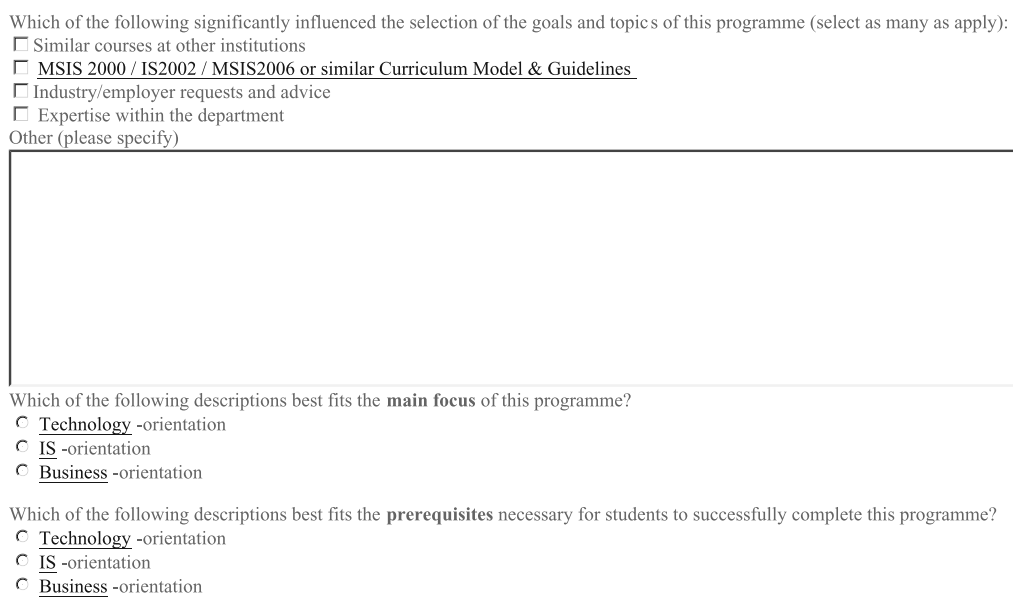

\begin{tabular}{|c|c|c|c|c|c|}
\hline Point Allocation & & & & & $\checkmark 100$ \\
\hline $\begin{array}{l}\text { Information and } \\
\text { Communication Technology }\end{array}$ & 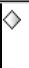 & 0 & Programming and Algorithms & $\beta$ & 0 \\
\hline Mathematics and Logic & $\diamond$ & 0 & Structural Science & 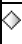 & 0 \\
\hline Accounting and Finance & $\diamond$ & 0 & $\begin{array}{l}\text { Marketing, Production, } \\
\text { Procurement, Logistics }\end{array}$ & $\Delta$ & 0 \\
\hline $\begin{array}{l}\text { Organization, human resource } \\
\text { and corporate management }\end{array}$ & 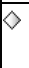 & 0 & $\begin{array}{l}\text { Legislation and legal } \\
\text { Regulations }\end{array}$ & 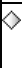 & 0 \\
\hline $\begin{array}{l}\text { Fundamentals of Information } \\
\text { Systems }\end{array}$ & $\diamond$ & 0 & $\begin{array}{l}\text { Principals of Business } \\
\text { Informatics }\end{array}$ & 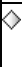 & 0 \\
\hline Data Engineering & $\phi$ & 0 & $\begin{array}{l}\text { System and Software } \\
\text { Engineering }\end{array}$ & $\Delta$ & 0 \\
\hline $\begin{array}{l}\text { Managing Data } \\
\text { Communication and } \\
\text { Networking }\end{array}$ & 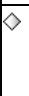 & 0 & Information Management & 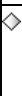 & 0 \\
\hline $\begin{array}{l}\text { Business Engineering and } \\
\text { Information System } \\
\text { Architecture }\end{array}$ & $\nabla$ & 0 & $\begin{array}{l}\text { Integrating Information } \\
\text { System Functions, Processes } \\
\text { and Data }\end{array}$ & $\gg$ & 0 \\
\hline $\begin{array}{l}\text { Integrating Information } \\
\text { System Technology and } \\
\text { Systems }\end{array}$ & $\phi$ & 0 & $\underline{\text { Interpersonal skills }}$ & $\Delta$ & 0 \\
\hline Teamwork and Leadership & $\diamond$ & 0 & Communication skills & $\diamond$ & 0 \\
\hline
\end{tabular}




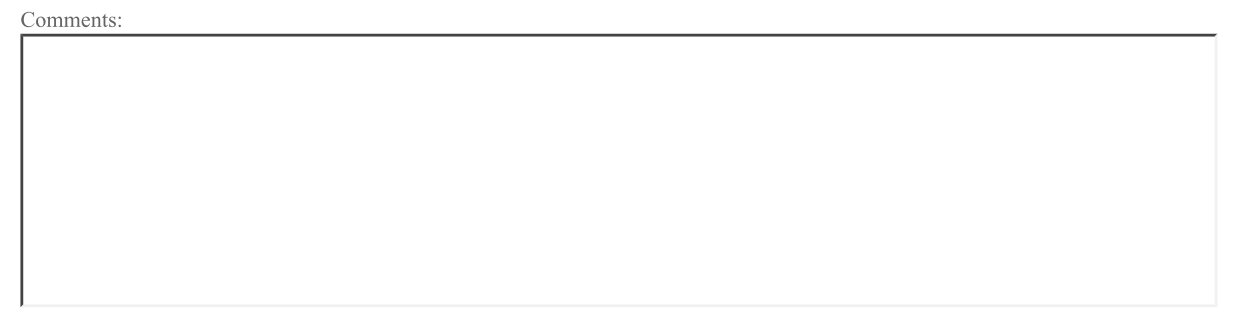

M. Helfert is a lecturer in information systems, head of the Business Informatics Group and chair of the European MSc in Business Informatics at the School of Computing, Dublin City University, Ireland. He holds a doctor in business administration from the University of St. Gallen, Switzerland, a master-diploma in business informatics from the University Mannheim, Germany, and a bachelor of science from Napier University, Edinburgh, UK-Scotland. His research interest is focused on business informatics, information systems, information quality and information management.

\section{Informaciniu sistemu ir verslo informatikos studiju programu ypatybès}

\footnotetext{
Markus HELFERT

Informacinès sistemos yra akademinė ir profesinè disciplina, jungianti verslą ir informatiką. Per pastaraji dešimtmetị informacinių sistemų kūrejjų ir vartotojų bendruomenejje vyko aktyvi diskusija apie šios disciplinos pagrindines sąvokas ir ypatybes. Tebevyksta debatai dèl informacinių sistemu absolventų esminiu igūdžiu ir gebejjimų. Straipsnio autorius sukūrẻ informacinių sistemų studiju programos struktūrizavimo sistemą bei charakterizavo kai kuriuos studiju programų skirtumus. Rezultatai grindžiami atliktos apklausos išvadomis.
} 